Rechtsmedizin $2022 \cdot 32: 401-406$ https://doi.org/10.1007/s00194-021-00546-w Accepted: 27 October 2021 Published online: 3 December 2021 (c) The Author(s) 2021

\section{Unexpected spotlight on two unusual substances}

\author{
Johann Zwirner ${ }^{1,2,3} \cdot$ Jan Dreßler ${ }^{3} \cdot$ Tanja Gradistanac ${ }^{4} \cdot$ Dustin Möbius $^{2} \cdot$ Carolin Edler $^{2}$. \\ Benjamin Ondruschka ${ }^{2}$ \\ 'Department of Anatomy, University of Otago, Dunedin, New Zealand \\ ${ }^{2}$ Institute of Legal Medicine, University Medical Center Hamburg-Eppendorf, Hamburg, Germany \\ ${ }^{3}$ Institute of Legal Medicine, University of Leipzig, Leipzig, Germany \\ ${ }^{4}$ Institute of Pathology, University of Leipzig, Leipzig, Germany
}

\title{
Abstract
}

Acute liver failure (ALF) is a rare and unexpected condition, which is commonly related to drug ingestion and viral infections. Here, two ALF fatalities are presented, which showed a rapid progression between the onset of symptoms and death. Both cases gained attention as unusual substances were suspected to be the reason for the fatal ALF, namely the prescription-free natural remedy Iberogast ${ }^{\circledR}$ (Bayer Vital GmbH, Leverkusen, Germany) and freely available energy drinks. Autopsy findings revealed that the fatal ALFs were unrelated to the ingestion of these two substances.

\section{Keywords}

Acute liver failure · Autopsy · Energy drink · Hepatotoxicity · lberogast ${ }^{\circledR}$

\section{Introduction}

Acute liver failure (ALF) is an unexpected condition that affects between one and six people per million in developed countries annually $[7,8,13]$. The ALF mortality ranges between $30 \%$ and $47 \%$ [27, 28, 31]. The most common causes of ALF include drug-induced injuries and viral infections [5], which show geographic prevalence variations [27]. The ingestion of paracetamol accounts for approximately $45 \%$ of all ALF cases in Denmark, whereas it is negligible in Hong Kong (see appendix P4 of [27]). Vice versa, approximately $45 \%$ of all ALF cases in Hong Kong are caused by hepatitis $B$, whereas this is almost absent in Denmark (see appendix P4 of [27]). The ALFs caused by malignant liver infiltrations are rare with only between $0.4 \%$ [23] and $1.8 \%$ [19] of all cases. Indeterminate ALFs, in which the specific etiology cannot be established, make up between $11 \%$ and $12 \%$ of ALF cases according to the two largest studies on the topic in the western world $[6,21]$. A recent closer examination of indeterminate ALF cases by a Causality Adjudication Committee formed by six experienced hepatologists of the United States
Acute Liver Failure Study Group revealed that about half of the indeterminate cases could be reassigned to one defined etiology after additional investigations [15]. Therefore, true indeterminate ALFs are as low as $5.5 \%$, if the best possible diagnostic opportunities are available and highly experienced doctors are dealing with these specific cases. For the truly indeterminate ALFs, suggested reasons include unrecognized viral infections [25] or incomplete patient evaluations [27]. Theoretically, indeterminate ALFs could be brought about by any hepatotoxic substance. Given the high mortality and the often rapid progression of ALFs in general, autopsies including toxicological analyses are important postmortem tools to follow up on the ALF etiology, which is important for cause of death statistics and the feedback for clinical colleagues. Here, two fatal ALF cases are presented, for which clinically no particular etiology could be established. In both cases, forensic autopsies were instigated as non-natural causes of death were suspected. Those cases are remarkable as unusual substances were suspected to be the reason for the fatal ALFs, namely the prescription-free natural remedy lberogast ${ }^{\circledR}$ 

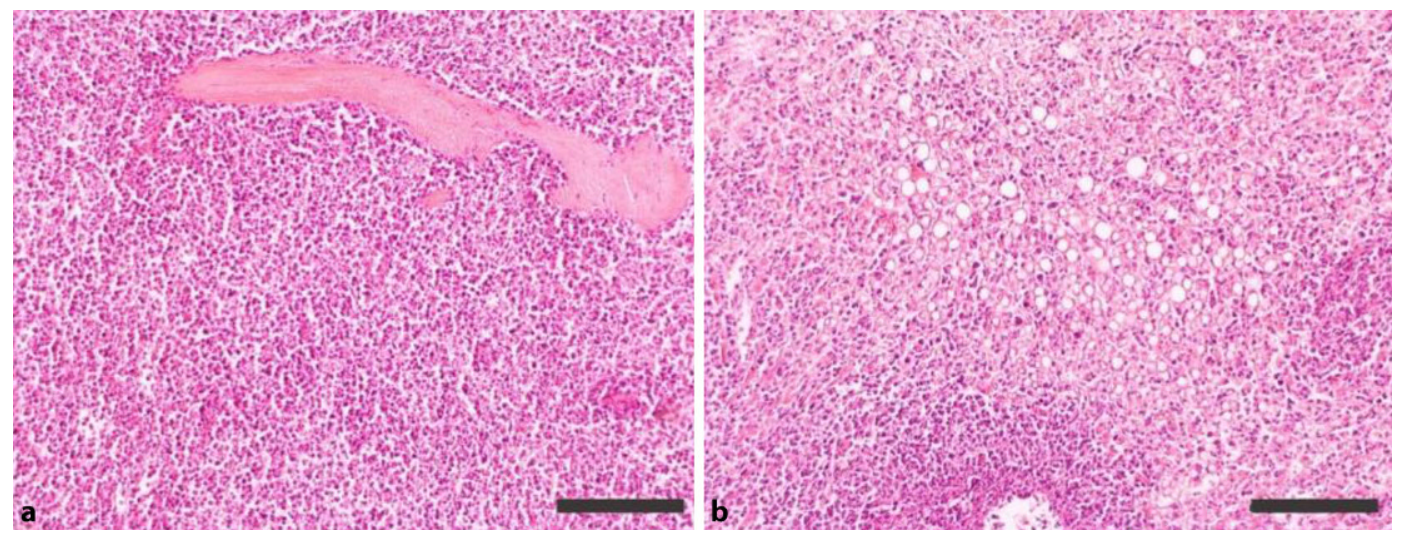

Fig. $1 \varangle$ The T-cell nonHodgkin lymphoma is depicted in H\&Estained slices, covering approximately $80 \%$ of the parenchyma of the spleen (a) and approximately $40 \%$ of the parenchyma of the liver (b). Magnification 10x, scale bar: $200 \mu \mathrm{m}$
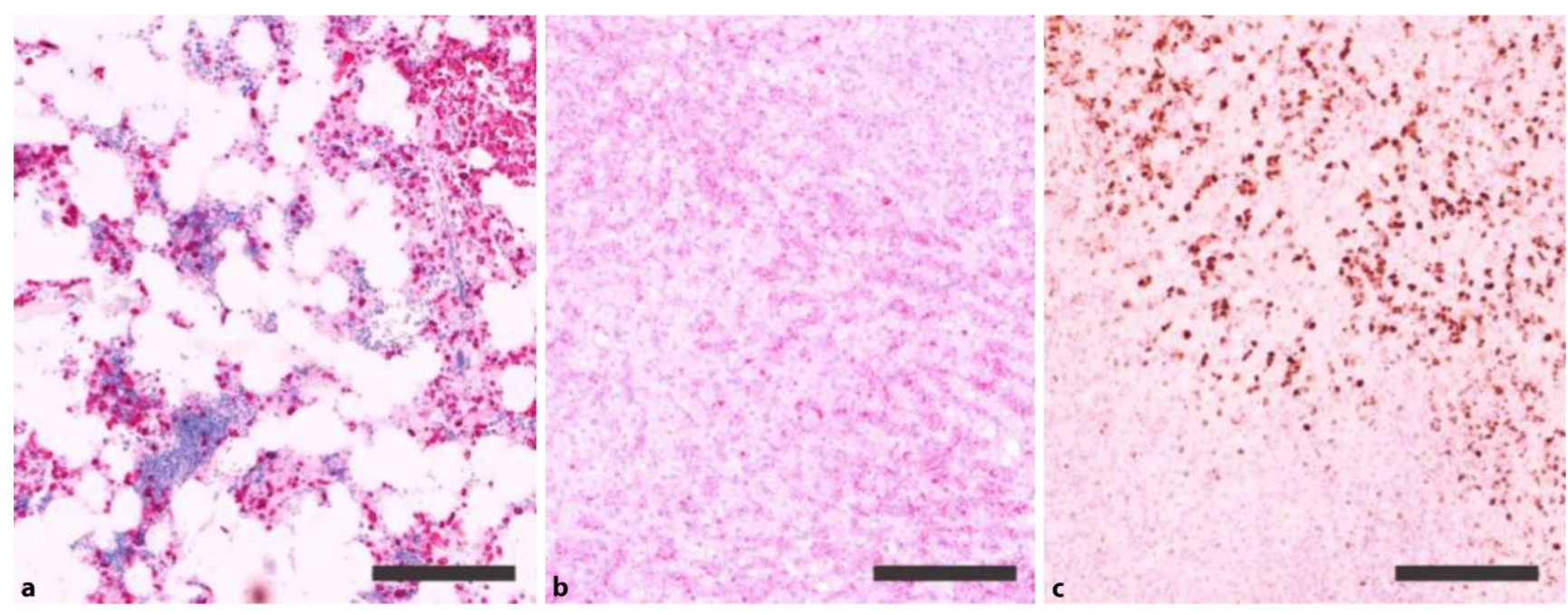

Fig. $2 \Delta$ Further immunohistochemical tissue sections of the infiltrative T-cell non-Hodgkin lymphoma showed a masses of CD3-positive cells in bone marrow, $\mathbf{b}$ diffuse CD8-positive cells in the liver and c a Ki67 (proliferation marker) proliferation rate of approximately $60 \%$ as identified with the MIB-1 antibody in the liver parenchyma. a-c Magnification 10x, scale bar: $200 \mu \mathrm{m}$

(Bayer Vital GmbH, Leverkusen, Germany) and freely available energy drinks.

\section{Case presentations}

\section{Case 1}

\section{History}

A 24-year-old male was hospitalized due to a loss of appetite, nausea and pain in the right hypochondrium, which initially occurred two days earlier. A laboratory blood test revealed increased liver enzymes and a computed tomography (CT) scan indicated a hepatosplenomegaly without solid organ lesions. The intake of ethanol, methanol, drugs, mushrooms or antifreeze was denied; however, the patient indicated a frequent consumption of energy drinks. During the following two days, the patient developed an ALF that led to a progressive multiorgan failure with severe lactate acidosis and an abnormal breathing pattern. Another CT scan negated signs of a portal vein thrombosis or a thrombosis of the liver veins but indicated swollen lymph nodes at the porta hepatis. Signs of infection were absent in extensive virological and microbiological screening tests. Intensive care procedures such as plasmapheresis and continuous renal replacement therapy failed to stop the treatment-refractory multiorgan failure and the patient died three days after being initially hospitalized. On account of the rapid worsening of the situation in the presented case from being subjectively healthy up to the fatal outcome five days later in a young patient, the manner of death was classified as undetermined. A forensic autopsy was requested to clarify whether the fatal outcome could be explained by a toxic effect of a previous food or drug intake (especially the con- sumption of energy drinks) or whether any other cause of death could be determined.

\section{Autopsy results}

The forensic autopsy confirmed the hepatosplenomegaly with a liver weight of $3960 \mathrm{~g}$ (expected mean weight 1769-1831 g [12]) and a spleen with an organ size of $24 \times 15 \times 11 \mathrm{~cm}$ and a weight of $1120 \mathrm{~g}$ (expected mean weight 175-180 g [12]). The liver borders were rounded with the right liver border reaching down to the right iliac region and the left liver border up to the left inner cusp of the rib cage. The liver parenchyma presented a firm and homogeneous structure with some macroscopically degenerated areas and few spots showing fatty infiltration, which were predominantly close to the capsule. The absence of thrombi in the liver veins as well as the portal vein was confirmed radiologically. Further autopsy 

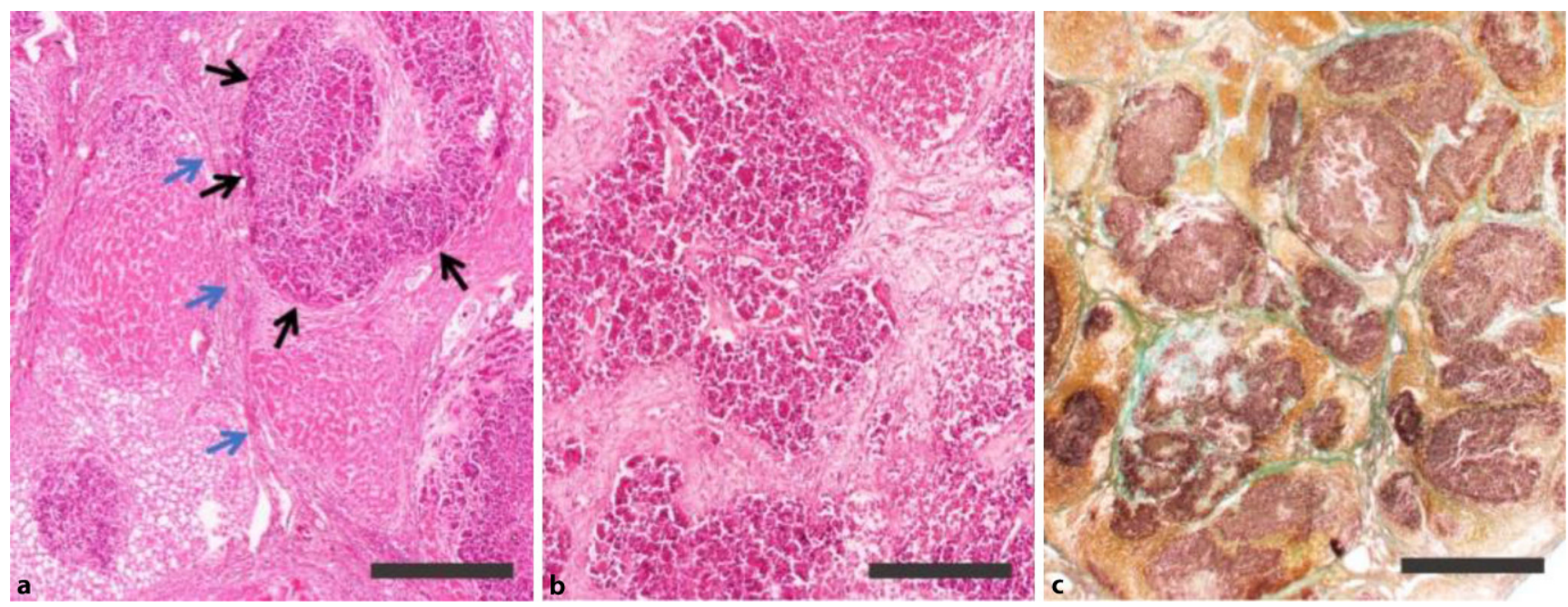

Fig. $3 \Delta$ Histological stains of the liver parenchyma are shown. a Septae (blue arrows) as a sign for liver cirrhosis are visible. Lawn-like basophilic infiltrations of a neuroendocrine tumor (small cell lung cancer) (black arrows) are visible adjacent to the septae. Magnification: $4 \times$, scale bar: $200 \mu \mathrm{m}$. b The core of the basophilic infiltrations reveals diffuse fibrotic streaks that are surrounded by pleomorphic basophilic neuroendocrine tumor cells. Magnification: 10X, scale bar: $500 \mu \mathrm{m}$. c Diffuse tumor infiltration with respect to the liver septae in Masson-Goldner staining. Magnification: 1×, scale bar $2 \mathrm{~mm}$

findings substantiated a multiorgan failure dominated by an initial ALF.

\section{Histological findings}

Histologically, a hepatosplenic T-cell nonHodgkin lymphoma (Cluster of differentiation (CD)3/CD8 positive, - Figs. 1 and 2) was detected in the liver, spleen and bone marrow samples. A routine toxicological analysis revealed traces of painkillers and antiemetics. Consequently, the death was classified as natural.

\section{Case 2}

\section{History}

A 70-year-old female was discharged from the hospital against medical advice after presenting with abdominal pain. Evaluation upon initial presentation showed coarsely granular liver cirrhosis with little ascites. Initially, a hepatocellular carcinoma was proposed as the cause for the symptoms; however, this was revised upon readmission of the patient to hospital three days later, when the patient presented complaining about feeling unwell. Here, liver sonography and abdominal CT described signs of liver cirrhosis without signs of malignancy. The patient reported that she suffered from enterospasms and pain in the upper abdomen for the last few weeks, which was treated by self- medication with the plant-based remedy Iberogast ${ }^{\circledR}$.

The patient became unresponsive four days later as a result of an ALF, which clinically presented with Kussmaul's breathing, elevated transaminases and spontaneous hypoglycemia. Plasmapheresis was initiated on suspicion of an ALF due to toxic hepatitis. Despite this and continuous dialysis, diffuse multifocal bleedings presented as a sign of severe coagulopathy. Finally, the rapidly progressive ALF led to the death of the patient. The manner of death was ruled as non-natural. A toxic ALF following the intake of the plant-based remedy lberogast ${ }^{\circledR}$, for which ALFs were reported previously [16, 24], was suspected. A considerable elevation of transaminases was deemed to be incompatible with death as a consequence of a chronic liver failure. An autopsy was initiated upon suspicion of a toxic ALF.

\section{Autopsy results}

At autopsy, a metastasized lung cancer with a $1.5 \mathrm{~cm}$ diameter node in the lingula of the left lung was found, which was not diagnosed during lifetime. Multiple metastases were found including the pleura, primary bronchi, lymph nodes next to the abdominal aorta and liver. Upon gross examination, the liver revealed mixed nodular cirrhosis with broad streaks ("roads") of connective tissue and regenerative nodes throughout the entire liver parenchyma (- Fig. 3). The spleen showed a hyaline perisplenitis with chronic congestion ( $160 \mathrm{~g}$ in weight). A few bleedings were present in the gastric mucosa.

\section{Histological findings}

Histologically, the liver revealed fibrosisforming septae and cirrhosis with signs of chronicinflammation (partly chloroacetate esterase-positive),some proliferations of the bile duct and fatty infiltration of $40 \%$ hepatocytes. A diffuse hepatocellular necrosis with destruction of single cells as well as cell groups was noted. Histological sections of liver cirrhosis were accompanied by lobulated basophilic tumor cells. A lawn-like spread of these neuroendocrine cells followed the segments of the liver cirrhosis (- Fig. 3). The immediate cause of death was recorded as being an ALF resulting from diffuse liver metastases that were caused by progressive small cell lung cancer. Chronic liver cirrhosis was attributed to nutritive (ethyl) toxic damage. A curative therapy was not possible in this case leading to the cause of death being classified as natural. According to the distinct autopsy findings, no toxicological investigations were performed. 


\section{Discussion}

Here, two fatal outcomes of rapidly progressive malignant diseases are presented, which were initially characterized as undetermined and non-natural causes of death according to the clinical diagnoses. In both cases, routine clinical imaging techniques failed to diagnose the real underlying causes of the respective ALFs. In the first case, the rapid organ failure of a 24-year-old male was suspected to be linked to the consumption of energy drinks. The second case, a 70-year-old woman who suffered a fatal fulminant liver failure, was thought to be a complication of self-medication with the plantbased remedy lberogast ${ }^{\circledR}$. In both cases, the forensic autopsy could precisely define the cause of death, which revealed that the outcome of both cases was clearly an unavoidable consequence of undetected malignant diseases rather than the clinical management. Unexpected sudden deaths due to undiagnosed malignancies can sometimes be detected by forensic autopsies $[4,11,26]$. Collaborative work between pathologists and clinicians is invaluable to constantly reassure and improve clinical practice and should be encouraged wherever possible. Furthermore, the autopsies enabled a correct classification of the fatalities in the national mortality statistics, which is paramount for decision-making processes in the healthcare sector, especially with respect to the distribution of resources [20]. A Norwegian study of 1773 deaths showed that an autopsy led to changes in the underlying cause of death in $61 \%$ of cases with major changes including ICD-10 code changes in approximately half of those cases [2]. Therefore, an autopsy should be prompted whenever the cause of death cannot be established with reasonable certainty from the medical history or the following external post-mortem. The cases presented here show that an autopsy is often the only tool to accurately confirm the cause of death, which once again underlines its value for the impact on the cause of death statistics. A brief outline is given below stating why the clinical assumptions of the rather unusual substances that potentially caused the fatal ALFs were justified and rightfully led to a subsequent autopsy.
Reasons why an autopsy was rightfully instigated to exclude the toxic effect of energy drinks as the cause of death

A considerable amount of negative shortterm and long-term health effects was noted after the consumption of energy drinks [1]. Concerningly, the toxicity of several widely used energy drink ingredients such as taurine, niacin and pyridoxine is not yet fully understood [32]. For example, the liver toxicity of niacin was shown before in several cases [9]. Hepatotoxic effects of freely available energy drinks were shown in patients both with and without comorbidities [3, 10, 17, 22, 29]. An otherwise healthy 22-year-old woman developed acute hepatitis that was attributed to excessive energy drink consumption during the two weeks before the diagnosis was made after other common hepatitis causes were excluded [29]. A 17-year-old boy with a history of ongoing fatigue during the two previous years was diagnosed with nonalcoholic steatohepatitis after an ongoing excessive energy drink consumption [22]. With respect to cases that presented additional comorbidities, a 16-year-old male who was treated with tacrolimus following liver transplantation developed cholestatic hepatitis after energy drink consumption and the concomitant intake of ibuprofen, which normalized within the next eight months [3]. Moreover, acute hepatitis was diagnosed in a 50-year-old HCV-positive male following daily consumption of "four to five" energy drinks for three weeks in a row [17]. Another case report mentioned that an energy drink consumption caused an elevation of aspartate aminotransferase, alanine transaminase and lactate dehydrogenase in a 38-year-old man suffering from HIV and diabetes [10]. The comorbidities were treated with combined antiretroviral therapy and metformin [10]. In all the mentioned cases the liver injury was attributed to energy drinks after other common causes were excluded or considered unlikely to be the reason for the hepatitis $[3,10,17,22,29]$. Additionally, the aforementioned cases had in common that the liver enzymes recovered after the intake of energy drinks was stopped [3, 10, 17, 22, 29]. Regarding the fatality presented here, the death was ex- plained by a hematological malignancy. The diagnosed hepatosplenic T-cell nonHodgkin lymphoma is a very rare disease accounting for approximately $2 \%$ of all T-cell lymphomas [14].

Reasons why an autopsy was rightfully instigated to exclude the toxic effect of Iberogast ${ }^{\circledR}$ as the cause of death

Iberogast ${ }^{\circledR}$ is a widely consumed remedy based on nine different herbs [24], which was shown to be superior to a placebo when treating functional dyspepsia [30] and irritable bowel syndrome [18]. Liver toxicity of lberogast ${ }^{\circledR}$ was not observed within the first 50 years after the remedy had been introduced onto the market even though special interest was given to the liver values as the celandine herbs were shown to be hepatotoxic before [18, 24]. It is hypothesized that the hepatocellular injury pattern is correlated with an idiosyncratic reaction with a metabolic subtype [24]; however, as the celandine herbs are only about $3 \%$ of the known hepatotoxic dose of a common daily dose of Iberogast ${ }^{\circledR}$, no hepatotoxic cases were confirmed after intake of lberogast ${ }^{\circledR}$ until the year $2016[18,24]$. Then, a 37-year-old man had to undergo liver transplantation after an ALF that was "potentially associated" with Iberogast ${ }^{\circledR}$ [24]. Recently, an Iberogast ${ }^{\circledR}$-induced ALF was reported in a 56-year-old woman to treat an abdominal discomfort [16]. The woman was on an ongoing treatment with medically prescribed valsartan (arterial hypertension) and metamizole (chronic pain syndrome) at the same time of the event [16]. Furthermore, the former group observed an additive hepatotoxic effect of metamizolelberogast ${ }^{\circledR}$ on the monocyte-derived hepatocyte-like cells in a laboratory experiment [16]. In this respect, it was recommended to carefully check the concomitant medication, aminotransferases and consider stopping lberogast ${ }^{\circledR}$ intake when liver enzymes are elevated [16]. In the case presented here, unknown amounts of lberogast ${ }^{\circledR}$ were repetitively consumed over weeks followed by a progressive liver failure resulting in death of the patient.

Post-mortem investigations in the cases presented here were able to disprove the 
suspicion that hepatotoxic effects of the natural remedy lberogast $^{\circledR}$ and energy drinks were the reason for the presented fatal ALFs while both patients died from diffuse hepatic infiltrates of aggressive tumors. Autopsy findings provided important feedback for clinical practice around patient management and helped to correctly classify rare and clinically undetermined diseases for the national cause of death statistics.

\section{Conclusion}

These case studies show that forensic medicine investigates unusual traces objectively. In both cases, an autopsy was necessary to correctly classify the respective cause of death. A forensic examination is an important tool for controlling legal substances which usually are harmless, but could cause incalculable effects in some instances. Autopsies are invaluable to correctly determine the cause of death in cases that show a rapid clinical progression, such as rare forms of ALF. Thereby, autopsy findings provide important feedback for clinical practice, aid in constantly monitoring the effects of accredited foods and drugs and help to correctly classify the cause of death for national registers with implications for resource allocations.

\section{Corresponding address}

\section{Benjamin Ondruschka}

Institute of Legal Medicine, University Medical Center Hamburg-Eppendorf

Hamburg, Germany

b.ondruschka@uke.de

Funding. Open Access funding enabled and organized by Projekt DEAL.

\section{Declarations}

Conflict of interest. Johann Zwirner, Jan Dreßler, Tanja Gradistanac, Dustin Möbius, Carolin Edler and Benjamin Ondruschka declare that they have no competing interests.

The investigations were carried out according to the specifications of the Central Ethics Committee of the Federal Medical Council.

Open Access. This article is licensed under a Creative Commons Attribution 4.0 International License, which permits use, sharing, adaptation, distribution and reproduction in any medium or format, as long as you

\section{Zwei ungewöhnliche Substanzen unerwartet im Rampenlicht}

Das akute Leberversagen ist eine seltene und oft unerwartete Todesursache. Hier werden 2 Fälle vorgestellt, die einen rasch-progredienten Verlauf zwischen dem Auftreten erster Symptome und dem letalen Ausgang aufwiesen. Die Besonderheit der präsentierten Fälle liegt darin, dass durch die vorherige Einnahme des Naturheilmittels Iberogast ${ }^{\circledR}$ (Bayer Vital GmbH, Leverkusen, Deutschland) und gewöhnlicher Energydrinks 2 Substanzen zur Autopsie veranlassten, deren Lebertoxizität ebenso unerforscht wie potenziell unterschätzt ist. Die rechtsmedizinische Leicheneröffnung konnte beide Substanzen zweifelsfrei entlasten.

\section{Schlüsselwörter}

Akutes Leberversagen · Autopsie · Energydrink · Lebertoxizität· lberogast ${ }^{\circledR}$

give appropriate credit to the original author(s) and the source, provide a link to the Creative Commons licence, and indicate if changes were made. The images or other third party material in this article are included in the article's Creative Commons licence, unless indicated otherwise in a credit line to the material. If material is not included in the article's Creative Commons licence and your intended use is not permitted by statutory regulation or exceeds the permitted use, you will need to obtain permission directly from the copyright holder. To view a copy of this licence, visit http://creativecommons.org/licenses/by/4.0/.

\section{References}

1. Al-Shaar L, Vercammen K, Lu C, Richardson S, Tamez M, Mattei J (2017) Health effects and public health concerns of energy drink consumption in the United States: a mini-review. Front Public Health 5:225

2. Alfsen GC, Maehlen J (2012) The value of autopsies for determining the cause of death. Tidsskr Nor Laegeforen 132:147-151

3. Apestegui CA, Julliard O, Ciccarelli O, Ho Minh Duc DK, Lerut J (2011) Energy drinks: another red flag for the liver allograft. Liver Transpl 17:1117-1118

4. Barranco R, Bedocchi D, Bonsignore A, Drommi M, Buffelli F, Fulcheri E, Ventura F (2021) Sudden and unexpected death in childhood due to an undiagnosed hepatoblastoma: case report and review of literature. J Forensic Leg Med 77:102086

5. Bernal W, Auzinger G, Dhawan A, Wendon J (2010) Acute liver failure. Lancet 376:190-201

6. Bernal W, Hyyrylainen A, Gera A, Audimoolam VK, McPhail MJW, Auzinger G, Rela M, Heaton N, O'Grady JG, Wendon J, Williams R (2013) Lessons from look-back in acute liver failure? A single centre experience of 3300 patients. J Hepatol 59:74-80

7. BowerWA, Johns M, Margolis HS, Williams IT, BellBP (2007) Population-based surveillance for acute liverfailure. Am J Gastroenterol 102:2459-2463

8. Brandsaeter B, Hockerstedt K, Friman S, Ericzon BG, Kirkegaard $\mathrm{P}$, Isoniemi $\mathrm{H}$, Olausson $\mathrm{M}$, Broome $\mathrm{U}$, Schmidt L, Foss A, Bjøro K (2002) Fulminant hepatic failure: outcome after listing for highly urgent liver transplantation - 12 years experience in the nordic countries. Liver Transpl 8:1055-1062

9. Brown AC (2017) Liver toxicity related to herbs and dietary supplements: online table of case reports. Part 2 of 5 series. Food Chem Toxicol 107:472-501
10. Cattaneo D, Riva A, FiliceC, GervasoniC (2020) Liver injury after occasional energy drink use in a patient living with HIV and diabetes. Ann Pharmacother 54:292-293

11. Chinen K, Kurosumi M, Ohkura Y, Sakamoto A, Fujioka $Y$ (2006) Sudden unexpected death in patients with malignancy: a clinicopathologic study of 28 autopsy cases. Pathol Res Pract 202:869-875

12. de la Grandmaison GL, Clairand I, Durigon M (2001) Organ weight in 684 adult autopsies: new tables for a Caucasoid population. Forensic Sci Int 119:149-154

13. Escorsell A, Mas A, Spanish Group for the Study of Acute Liver Failure (2007) Acute liver failure in Spain: analysis of 267 cases. Liver Transpl 13:1389-1395

14. Foss FM, Horwitz SM, Civallero $M$, Bellei $M$, Marcheselli L, Kim WS, Cabrera ME, Dlouhy I, Nagler A, Advani RH, Pesce EA, Ko YH, Montoto S, Chiattone C, Moskowitz A, Spina M, Cesaretti M, Biasoli I, Federico M (2020) Incidence and outcomes of rare T cell lymphomas from the T cell project: hepatosplenic, enteropathy associated and peripheral gamma delta T cell lymphomas. Am JHematol 95:151-155

15. Ganger DR, Rule J, Rakela J, Bass N, Reuben A, Stravitz RT, Sussmann N, Larson AM, James L, Chiu C, Lee WM, Acute Liver Failure Study Group (2018) Acute liver failure of indeterminate etiology: a comprehensive systematic approach by an expert committee to establish causality. Am J Gastroenterol 113:1319

16. Gerhardt F, Benesic A, Tillmann HL, Rademacher $S$, Wittekind C, Gerbes AL, Henker R, Berg T, Maidh of HP, Trauer H, Wiegand J (2019) Iberogastinduced acute liver failure-reexposure and in vitro assay support causality. Am J Gastroenterol 114:1358-1359

17. Harb JN, Taylor ZA, Khullar V, Sattari M (2016) Rare cause of acute hepatitis: a common energy drink. BMJCase Rep 2016:bcr2016216612

18. Madisch A, Holtmann G, Plein K, Hotz J (2004) Treatment of irritable bowel syndrome with herbal preparations: results of a double-blind, randomized, placebo-controlled, multi-centre trial. Aliment Pharmacol Ther 19:271-279

19. Nakao M, Nakayama N, Uchida Y, Tomiya T, Ido A, Sakaida I, Yokosuka O, Takikawa Y, InoueK, Genda T, Shimizu M, Terai S, Tsubouchi H, Takikawa H, Mochida S (2018) Nationwide survey for acute liver failure and late-onset hepatic failure in Japan. JGastroenterol 53:752-769 
20. Nielsen GP, Bjornsson J, Jonasson JG (1991) The accuracy of death certificates. Implications for health statistics. Virchows Arch A Pathol Anat Histopathol 419:143-146

21. Reuben A, Tillman H, Fontana RJ, Davern T, McGuire B, Stravitz RT, Durkalski V, Larson AM, Liou I, Fix O, Schilsky M, McCashland T, Hay JE, Murray N, Shaikh OS, Ganger D, Zaman A, Han SB, Chung RT, Smith A, Brown R, Crippin J, Harrison ME, Koch D, Munoz S, Reddy KR, Rossaro L, Satyanarayana R, Hassanein T, Hanje AJ, Olson J, Subramanian R, Karvellas C, Hameed B, Sherker AH, Robuck P, Lee WM (2016) Outcomes in adults with acute liver failure between 1998 and 2013: an observational cohort study. Ann Intern Med 164:724-732

22. Robin S, Buchanan R, Poole R (2018) Energy drinks and adolescents - a hepatic health hazard? JHepatol 68:856-857

23. Rowbotham D, Wendon J, Williams R (1998) Acute liver failure secondary to hepatic infiltration: a single centre experience of 18 cases. Gut 42:576-580

24. Saez-Gonzalez E, Conde I, Diaz-Jaime FC, Benlloch S, Prieto M, Berenguer M (2016) Iberogast-induced severe hepatotoxicity leading to liver transplantation. Am J Gastroenterol 111:1364-1365

25. Somasekar S, Lee D, Rule J, Naccache SN Stone M, Busch MP, Sanders C, Lee WM, Chiu CY (2017) Viral surveillance in serum samples from patients with acute liver failure by metagenomic next-generation sequencing. Clin Infect Dis 65:1477-1485

26. Somers GR, Smith CR, Perrin DG, Wilson GJ, Taylor GP (2006) Sudden unexpected death in infancy and childhood due to undiagnosed neoplasia: an autopsy study. Am J Forensic Med Pathol 27:64-69

27. Stravitz RT, Lee WM (2019) Acute liver failure. Lancet 394:869-881

28. Tessier G, Villeneuve E, Villeneuve JP (2002) Etiology and outcome of acute liver failure: experience from a liver transplantation centre in Montreal. Can J Gastroenterol 16:672-676

29. Vivekanandarajah A, Ni S, Waked A (2011) Acute hepatitis in a woman following excessive ingestion of an energy drink: a case report. J Med Case Rep 5:227

30. von Arnim U, Peitz U, Vinson B, Gundermann KJ, Malfertheiner P (2007) STW 5, a phytopharmacon for patients with functional dyspepsia: results of a multicenter, placebo-controlled double-blind study. Am J Gastroenterol 102:1268-1275

31. Weiler N, Schlotmann A, Schnitzbauer AA, Zeuzem S, Welker MW (2020) The epidemiology of acute liver failure. Dtsch Arztebl Int 117:43-50

32. Wolk BJ, Ganetsky M, Babu KM (2012) Toxicity of energy drinks. Curr Opin Pediatr 24:243-251

\section{In eigener Sache}

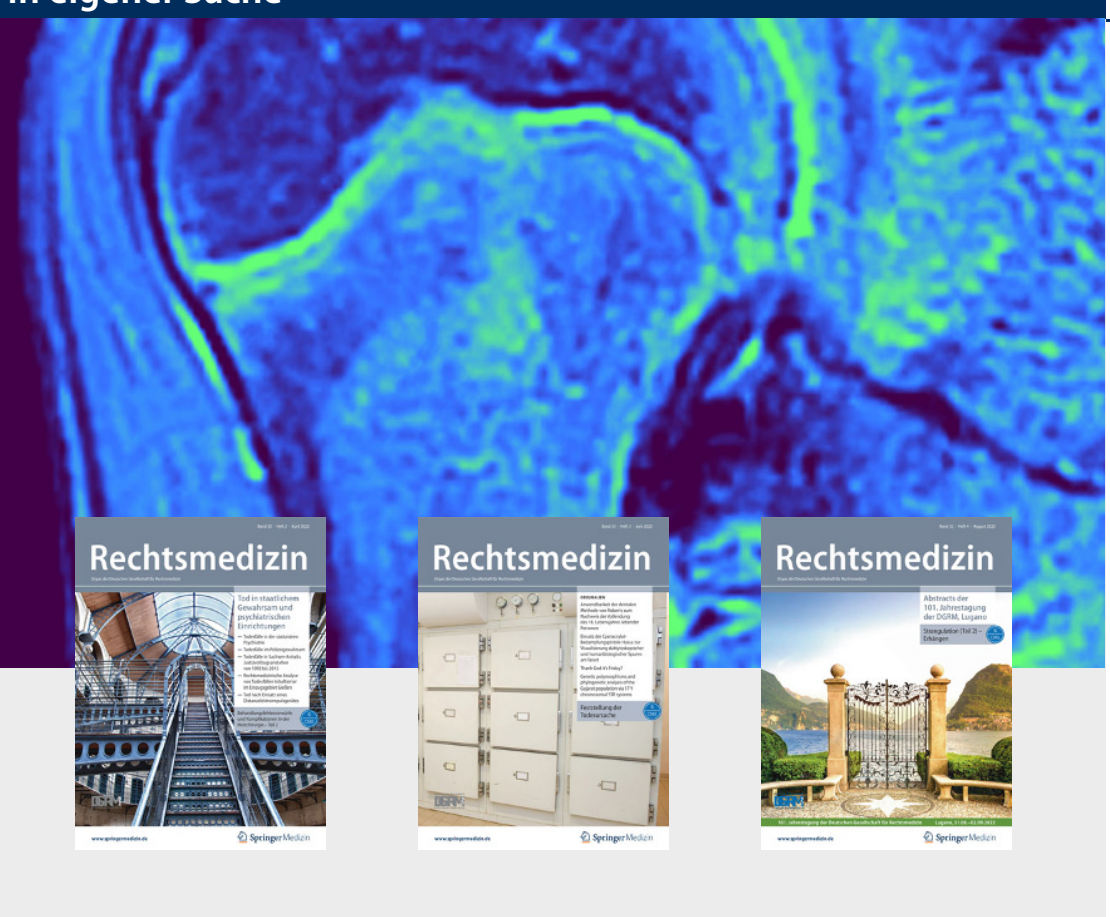

\section{Leitthemenübersicht Rechtsmedizin 2022}

Die Zeitschrift Rechtsmedizin bietet Ihnen jeden zweiten Monat umfassende und aktuelle Beiträge zu interessanten Themenschwerpunkten aus allen Bereichen der Rechtsmedizin.

$\begin{array}{ll}\text { - 01/2022 } & \text { Varia } \\ \text { - 02/2022 } & \text { Tod in staatlichem Gewahrsam } \\ \text { - 03/2022 } & \text { Varia } \\ \text { - 04/2022 } & \text { Kongressheft } \\ \text { - 05/2022 } & \text { Varia } \\ \text { - 06/2022 } & \text { Varia }\end{array}$

Alle Inhalte von Rechtsmedizin finden Sie unter www.springermedizin.de/rechtsmedizin.

SpringerMedizin.de bietet Ihnen Zugang zu allen elektronisch verfügbaren Ausgaben Ihrer Zeitschrift - unabhängig vom Beginn Ihres Abonnements.

Möchten Sie ein bereits erschienenes Heft nachbestellen? Einzelne Ausgaben können Sie direkt bei unserem Kundenservice zum Preis von je EUR 94,- zzgl. Versandkosten beziehen.

\section{So erreichen Sie unseren Kundenservice:}

Springer Customer Service Center GmbH

Kundenservice Zeitschriften

Tiergartenstr. 15, 69126 Heidelberg

Tel.: +49 $6221345-4303$

Fax: +49 $6221345-4229$

E-Mail: leserservice@springer.com 